Studia Anglica Posnaniensia 51/2, 2016

doi: 10.1515/stap-2016-0010

\title{
THE SWIFT AND SECRET MESSENGER: JOHN WILKINS'S MERCURY AND THE PARADOXES OF LANGUAGE
}

\author{
KLAUDIA ŁĄCZYŃSKA*
}

University of Warsaw

\begin{abstract}
John Wilkins's Mercury or the Secret and Swift Messenger: Showing How a Man May with Privacy and Speed Communicate His Thoughts to a Friend at Any Distance was first published in 1641. As a book on cryptography presenting a variety of secret means of communication at a distance it seems to have appeared at just the right time, when the biblical curse of the confusion of tongues was doubled by the curse of political confusion on the brink of the English civil war. However, the book seems to be more than just a detailed account of methods of secret writing; its topic gives the author a chance to present his views on language which he would later develop in his life's work An Essay towards Real Character and a Philosophical Language published in 1668. The Essay had received much greater critical attention than the early pamphlet, which is usually referred to as merely a prelude to an account of his universal language project. Indeed, in the little book on cryptography, Wilkins already demonstrated his awareness of the conventional character of language and its role within the system of human interactions, as well as advertised a project of philosophical language that would enhance communication between all nations and remedy the curse of Babel. The aim of this paper is to demonstrate that the value of the pamphlet lies also in the insight that it gives into the seventeenth-century debates on the nature of language and into arguments which were often provided, in equal measure, by theology, Hermetic lore, mythology, literature and early modern science. Wilkins's meticulous recording of the contradictory views and propositions on language produces a sense of methodological inconsistency that leads to ambiguities and paradoxes. However, in the medley of concepts and the collection of linguistic "curiosities" that Mercury presents, a careful reader will discern the growing mistrust of language as a means of representing reality and as a foundation of knowledge, which was one of the symptoms of the general crisis of representation leading to an epistemological shift that started in the seventeenth century.
\end{abstract}

Keywords: universal language, cryptography, John Wilkins, Mercury, philosophy of language

* Institute of English Studies, British Literature Department, ul. Hoża 69, 00-681 Warszawa, email: klaudialaczynska@wp.pl. 


\section{Introduction}

Mercury or the Secret and Swift Messenger: Showing How a Man May with Privacy and Speed Communicate His Thoughts to a Friend at Any Distance, published in 1641, is granted some scholarly recognition as being the first English-language book on cryptography, and as an early expression of John Wilkins's linguistic interests. The author of this curious work is, however, better known for his monumental work on universal language An Essay Towards a Real Character and a Philosophical Language, published in 1668, and dedicated to The Royal Society, of which he was then a secretary. That truly is Wilkins's opus magnum - an extraordinary project of an artificial philosophical language which the author advertises as "the distinct expression of all things and notions that fall under discourse" (Essay, Epistle Dedicatory), which shall provide the Babel-cursed humanity with a universal means of communication. At the same time, it is Wilkins's most profound inquiry into the nature of language and meaning and a heroic attempt at a comprehensive dictionary of all things in the world. His Tables of "all things and notions" (Essay, Epistle Dedicatory) meticulously constructed in the Essay can be perceived, according to Werner Hüllen, as "the ordering system of a comprehensive thesaurus of the English language, $\ldots$ an onomasiological system of unprecedented complexity" (Hüllen 1999: 255). For Wilkins, they are nothing less than "the shortest and plainest way for the attainment of real Knowledge, that hath been yet offered to the World" (Essay, Epistle Dedicatory).

Modern scholarship usually groups Wilkins with Bacon, Dalgarno, Hobbes or Locke, as one of the philosophers writing on the defects of language and postulating its reform; in this group he is probably the most determined language reformer of the seventeenth century - his Essay perceived as the most advanced of the universal language projects of the time. ${ }^{1}$ While Wilkins is clearly aware of the possible deficiencies of his theory, which "must needs add much perplexity to any such Attempt" (Essay, 21), the scholars frequently point

1 The broadest view on universal language projects as a cultural phenomenon in Europe seems to be Umberto Eco's book The search for the perfect language: Making of Europe (1995). The most important and detailed studies of philosophical languages in the seventeenth-century England are (in order of publication): James Knowlson, Universal language schemes in England and France, 1600-1800 (1975), especially chapters 1-4; Murray Cohen, Sensible words: Linguistic practice in England, 1640-1785 (1977); M. M. Slaughter, Universal languages and scientific taxonomy in the seventeenth century (1982); Lia Formigari, Language and experience in 17th-century British philosophy (1988); Robert E. Stillman, The new philosophy and universal languages in seventeenth-century England: Bacon, Hobbes, and Wilkins (1995); Rhodri Lewis, Language, mind and nature: Artificial languages in England from Bacon to Locke (2007); A discussion of Wilkins's Essay as an example of a dictionary of English language is presented in Werner Hüllen's English dictionaries, 800-1700: The topical tradition (1999). 
to what they term "Wilkins paradox" - the Tables, which profess to be philosophical classifications of things and notions, mostly depend on the specific lexicon of the English language. Moreover, Wilkins's untiring, one may even say, heroic effort to produce a coherent taxonomy of all things ${ }^{2}$ has also been perceived as quixotic by some readers of his opus magnum. ${ }^{3}$

The aim of this article is to focus on Wilkins's Mercury, which has received far less critical attention than his later and more mature work, but seems to provide a crucial insight into the seventeenth-century paradigm shift, affecting the ways of understanding and describing the world. The issue at stake is not only recording an important episode in the historical evolution of the philosophy of language, which ultimately led to our contemporary view on human language as a product of custom and convention, but also an attempt to inscribe Wilkins's minor work in the mainstream seventeenth-century discussion on the nature of poetic speech in the realm of fallen human language (a potent question raised in Andrew Marvell's poetic endeavours and informing Milton's Paradise Lost), which, at the same time, led to efforts aimed at restoring the blameless transparency of Adamic speech, undertaken not only in theoretical deliberations, but manifest also in Hermetic lore, Neoplatonic allegory, and widespread popularity of emblem books.

Scholars writing about Wilkins mention his pamphlet briefly, either as an early expression of the philosopher's interest in language and of his desire to reform it, or in reference to one of the topics it covers (cryptography, allegory, metaphor, etc.). ${ }^{4}$ An interesting exception in this respect is the reference to Wilkins's book on cryptography in Umberto Eco's (1992: 40-41) Interpretation and Overinterpretation, where the author quotes Wilkins's story of a fig carrier. ${ }^{5}$

2 The author himself admits that the extent of his project requires "the combined Studies of many Students, amongst whom, the several shares of such a Work should be distributed" (Essay, Epistle Dedicatory), by which he seems to demonstrate the emergence of a modern awareness of an effective scientific research as a joint effort of a team of scholars, rather than a life-project of an individual.

3 In "The Analytical Language of John Wilkins", an essay which does not pretend to be a thorough analysis of Wilkins's method but is rather the author's reflection on an epistemological frame of the past, Jorge Luis Borges presents Wilkins's predilection for taxonomies and his desire to organise the world with a degree of sarcasm, but not without nostalgia for the relics of the early modern thought. Borges is clearly impressed by Wilkins's taxonomic endeavour, yet he ironically emphasises the arbitrariness of such systems by comparing Wilkins's Tables with an extreme example of ad hoc taxonomies - a curious classification of animals that, according to the author, comes from an unknown (or most probably nonexistent) Chinese encyclopaedia (Borges 2001: 229-232). According to Rhodri Lewis, Borges's text is marked by a "characteristic wryness on what he took to be the more quixotic aspects of Wilkins's Essay" (Lewis 2007: 3)

4 See Cohen (1977: 9), Formigari (1988: 15-17), Stillman (1995: 238), Lewis (2007: 42-44, 123).

5 For Wilkins's narration of the story see Mercury, 5-7. 
Eco employs the story to illustrate his thesis on the limits of interpretation, which seems to point to the fact that Wilkins's pamphlet can easily be used as a store of peculiar examples, a cabinet of curiosities. This is probably because to the modern reader, Mercury may appear to be a heterogeneous text, partly due to its topic and partly to the author's peculiar presentation of it. On the one hand, Wilkins demonstrates a scientific approach, when he enumerates and examines a variety of methods of cryptographic encoding, voicing certain observations which we recognise as familiar from the linguistic and generally scientific perspective. On the other hand, the passages in which the text refers to magic, telepathy, or angelic discourse may seem to approximate to the level of absurdity mocked in Jorge Louis Borges's outlandish catalogue; ${ }^{6}$ to us today, some of Wilkins's examples amount to what Michel Foucault called "the stark impossibility of thinking" (Foucault 1994: xv). This is because the modern reader is used to an entirely different "régime in discourse and forms of knowledge" (Foucault 1980: 112).

Thus, I would argue that if, from the point of view of the history of artificial language projects, Mercury seems a text of much lesser interest than Wilkins's later and more mature work, nonetheless, this early pamphlet sheds some light on the epistemological shift which started in the seventeenth century and manifested itself in "a modification in the rules of formation of statements which are accepted as scientifically true" (Foucault 1980: 112). Hence, while the pamphlet seems to present changing views on language, it also indicates what statements about language are possible in seventeenth-century philosophical discourse. In other words, Wilkins's Mercury, while demonstrating the conflict between contemporary concepts of language, points to the seventeenth-century crisis of discourse that laid the foundations of modern epistemology. It can be argued that Wilkins's inconsistencies of method and theoretical ambiguities are symptomatic of a general crisis of representation that manifested itself in the growing mistrust of language as a reliable representation of reality and as the basis of knowledge about the world. ${ }^{7}$

The modern reader of the pamphlet will be as much puzzled by Wilkins's strange categories and fantastic speculations as by his ostensibly matter-of-fact

6 The famous classification that comes from an unknown (or false) Chinese encyclopaedia (as Borges claims) divides animals into: a) belonging to the Emperor, b) embalmed, c) tame, d) suckling pigs, e) sirens, f) fabulous, g) stray dogs, h) included in the present classification, i) frenzied, j) innumerable, $k$ ) drawn with a very fine camelhair brush, 1) et cetera, $\mathrm{m}$ ) having just broken the pitcher, $n$ ) that from a long way off look like flies.

7 Richard Waswo presents this shift of paradigm in terms of transition from referential to relational semantics, and the dissociation of the linguistic sign from the world of things, see especially (Waswo 1987: 3-81). In comparison, Margreta de Grazia, situates the origins of the crisis primarily in the breaking of the relationship between human speech and the divine Word, which led to the secularisation of language in the seventeenth century (De Grazia 1980: 319). 
concessions to the plausible and practical. On the whole, the book seems less of an introduction to the art of cryptography, which a fledgling diplomat or an active spy might find useful, and more a miscellany of ancient sources, contemporary narratives, common views, and hearsay on various systems of communication - recondite, occult, natural, or philosophical. The author seems to be aware of the heterogeneous nature and little scientific merit of his book, when he admits, in the opening address to the Reader, that "the vanity of this age is more taken with matters of curiosity, than those of solid benefit" (Mercury, To the Reader). ${ }^{8}$ However, out of the meticulously catalogued, yet motley collection of curiosities concerning contemporary linguistic theory and practice, there definitely transpires Wilkins's predilection for cataloguing, as much as his personal fascination with the operations of language, which is marked, nevertheless, by anxiety about its ambivalent philosophical, political, or religious status.

\section{The intelligible and the corporeal}

Whatever accusations had been made against "impostures and cheats that are put upon men, under the disguise of affected insignificant Phrases" (Essay Epistle Dedicatory), ${ }^{9}$ Wilkins had to admit that life without the benefit of language would have been a misery. In Mercury, he clearly recognised the indispensability of that device. "It were a miserable thing for a rational Soul to be imprisoned in such a Body as had no way at all to express its Cogitations" (Essay, 114), he writes in chapter XIV, in a passage devoted to the sign language of the deaf and dumb. Wilkins seems very much taken with the latter method of communication and appreciates the fact that those to whom nature denied the advantage of speech, still had their "dialogues of gestures". Thus, paradoxically, the body is as much a blessing as it is a curse to the rational soul, being its prison and, at the same time, the only means of expression. When the reader is made aware of the paradox, a purely hypothetical solution is pronounced that is even more puzzling. How much simpler human discourse would have been, Wilkins ruminates, if we could communicate like angels, who "hear, and know, and speak, not with several parts, but with their whole

8 This quotation comes from the first edition of Mercury that appeared in 1641. Notably, this passage disappears from the 1694 edition, together with the preceding paragraph where Wilkins admits to the Reader that he did not publish his work "for the public good", but to "gratifie [his] brother the Stationer". All subsequent quotations from Wilkins's Mercury come from the 1694 edition, as I wanted to avoid the confusion which might be caused by the misnumbered pages of the first edition.

9 It has to be noted that John Locke uses a similar expression to discredit ornamental redundancies in language: "all the artificial and figurative applications of words eloquence hath invented, are for nothing else but to insinuate wrong ideas, move the passions, and thereby mislead the judgement; and so indeed are perfect cheats" (Locke 1996: 299). 
substance" (Mercury, 2). Naturally, the author is aware that when it comes to man, the body is an impediment to easy and immediate communication. Nonetheless, it provides those "Corporeal Instruments" for "the Receiving and Conveying of Knowledge" (Mercury, 2-3). That seems to be the author's partial concession to the corporeal nature of human language - the intelligible is doomed to depend upon the sensible for its expression; it has to be em-bodied and delivered into the time-bound material world. ${ }^{10}$

Indeed, the process is set out in a metaphor of childbirth by Wilkins's contemporary John Bulwer in Chirologia, published three years after the first appearance of Mercury. Like Wilkins, Bulwer despairs about the mental effort and time required to turn swift immaterial thoughts into a flow of words. Consequently, he considers alternative ways of communication as well as some possible means of assistance: “... there's no native law, or absolute necessity, that those thoughts which arise in our pregnant minde, must by mediation of our Tongue flow out in a vocall streame of words; unto which purpose we must attend the leisure of that inclosed instrument of speech". The "pregnant mind" may find an assistant in its "labours", because "the Hand, which is a ready Midwife, takes oftentimes the thoughts from the forestalled Tongue, making a more quick dispatch by gesture" (Chirologia 4, emphasis mine). Bulwer's metaphors conceptualise linguistic expression within the framework of gestation and birth - it is, thus, imagined as a process of passage; in this case, from the non-corporeal thought into the corporeal word and gesture. Hence, the natural language of gestures, that Bulwer wanted to rehabilitate in his book, is not exempt from the curse of the corporeal, even though it is, apparently, more natural and immediate than speech. It seems then that Bulwer grappled with the same condition of human linguistic activity that Wilkins recognised as well: the inevitable coexistence of and cooperation between the corporeal and the intelligible in the construction and expression of meaning.

\section{Catalogues of curiosities}

Remarkably, in Mercury, Wilkins quotes an example of human discourse which, ostensibly, escapes the sensible, as he briefly refers to the concept of thoughttransference disseminated by some Neoplatonists (in a note on the margin, Wilkins identifies Marsilio Ficino). This apparent momentary concession to the

10 Wilkins's notion of body and mind is clearly dualist. However, his recognition of the indispensability of the body in the expression of cogitations seems to be the author's brilliant, albeit vague, intuition of what is nowadays a crucial development in cognitive science - the concept of embodied cognition (or embodied mind) which draws attention to the experience of the body as the basis of conceptualisation and formation of meaning. For the concept of embodied cognition see, for example: Francisco J. Varela et al., The embodied mind: Cognitive science and human experience (1991). 
occult cannot be counted among those statements that would be accepted within modern scientific discourse. However, in Wilkins's heterogeneous work they can also be treated as nothing more than a manifestation of the author's natural predilection for taxonomies, which he fully realised in his opus magnum of 1668. Here, the penchant for cataloguing makes him include all known methods and all degrees of swiftness and secrecy in communication at a distance in the book which deals with cryptography. Accordingly, he dutifully cites the Neoplatonic concept of communication, but presents it as purely hypothetical, which is implied by the conditional clause:

There is nothing so swift ... as thought, and yet the impression of these in another,
might be as quick almost as the first act, if there were but such a great power in
imagination as some later Philosophers have attributed to it

(Mercury, 118-119, emphasis mine)

For similar reasons, it seems, he briefly toys with the idea of employing spirits or angels, considered to be the swiftest messengers, to carry messages between men. "If we could send but one of them [angels] upon any errand", Wilkins speculates, "there would be no quicker way than this for the dispatch of business at all distances" (Mercury, 120). Having provided some examples of non-corporeal messengers from ancient sources, Wilkins, nevertheless, concludes pragmatically and, indeed, very prudently that "it is not so easie to imploy a good Angel, nor safe dealing with a bad one" (Mercury, 122). While to us these observations may seem to be a crack in a proper scientific method, for Wilkins they might have constituted a way of plain dealing with a great variety of available data, as well as an unspoken desire of a mind confronted with the crisis of representation to find among the miscellany of "evidence" a stable ground upon which one may distinguish between an angel and a demon, good and evil, or truth and falsehood.

Moreover, in the light of this passage, the very title of Wilkins's pamphlet, which puts Hermes-Mercury right in the centre of our attention, betrays the author's genuine trust in hermetic philosophy and occult knowledge. In other words, Wilkins's digression on the speech of angels is clear evidence for Debora Kuller Shuger's thesis of the multiformity of the dominant culture. As she observes, in the early modern period, even at the threshold of the Age of Enlightenment, we constantly come across an overlapping of secular, "demystifying" (Raymond Williams would say: "emergent") and sacred, "mystifying" ("residual") elements of an epistemological paradigm (Shuger 1997: 20-22). 


\section{Adamic language versus philosophical language}

Considering human modes of expression, Wilkins finds them far from perfect, because they rely on the imperfect body, and, with this body, bear the mark of the Fall. As the author states at the beginning of chapter XIII, "after the Fall of Adam, there were two general Curses inflicted on Mankind: The one upon their Labours; the other upon their Language" (Mercury, 105). Certainly, Wilkins's concept of the origin of language is based on "the revelation of Scripture"; as he states at the beginning of the Essay, "the first Language was con-created with our first Parents" (Essay, 2). So, with the first parents it fell. In Mercury, Wilkins does not make it clear, however, whether the greatest damage to human language came with the Fall or with the confusion of Babel, when languages were multiplied. Be that as it may, the universal language including real characters, the "darling" dream the author advertises in chapter XIII of Mercury and realises over twenty years later in the Essay, is intended to remedy the multiplication of languages: “... the confusion at Babel might this way have been remedied, if every one could have expressed his own meaning by the same kind of Character" (Mercury, 106).

As the hardships of the first curse (that of man's labour), can be abated by "common Arts and Professions" (Mercury, 105), so it is in art that Wilkins looks for a means to restore linguistic unity. ${ }^{11}$ However, if an artificial universal language may obliterate the effects of the confusion of Babel, Wilkins never promises it would restore us to the pre-lapsarian original. Already in Mercury, he dismisses and ridicules the attempts of scholars "who have sought to find out the Primitive Tongue, by bringing up Infants in such silent, solitary places, where they might not hear the Speech of others" (Mercury, 4). In spite of his belief in linguistic monogenesis Wilkins rules out the possibility of retrieving the pre-lapsarian Adamic language. Among the obstacles that bar the way back to the common original is the diachronic change that all fallen human languages are subject to. ${ }^{12}$ Therefore, Wilkins postulates that none of the existing languages can be identified as natural or in-born. "Languages are so far Natural unto us, as other Arts and Sciences. A Man is born without any of them, but yet capable of all" (Mercury, 4).

11 The same ways of redressing the miseries of the two Curses were proposed by Bacon in The Advancement of Learning (1900: 168), which, together with many other echoes of Baconian thought to be heard in Mercury, points to the undeniable indebtedness of the author to "the learned Verulam", as he respectfully calls the great philosopher in the pamphlet (Mercury, 10).

12 See Subbiondo (1990: 357). 


\section{Natural and artificial signs}

It is difficult to determine whether Wilkins places language and its acquisition in the realm of Art or in that of Nature. In the Essay, he states with a high degree of definiteness that "there are no Letters and Languages that have been at once invented according to the Rules of Art, but that all, except the first ..., have been either taken up from that first and derived by way of Imitation; or else, in a long tract of time, have ... admitted various and casual alterations". As to that first language, we may only know for certain that "it was not made by human Art upon Experience" (Essay, 19). "Casual" seems the key word to the understanding of natural-artificial dichotomy which apparently underlies Wilkins's views on the origin and development of language(s). The development (or rather degeneracy) of natural languages is ruled by diachronic and "casual" change; in this sense the "natural" would be associated with random and time-bound. Accordingly, the "artificial" would be synonymous with the deliberate and methodical, and thus free from the defects of the "natural". Notably, if thus conceived, both the "artificial" and the "natural" involve human agency. Hence the man-made artificial philosophical language could remedy the man-inflicted corruptions and redundancies of the existing natural languages, because, paradoxically, it would be based on the careful observation of Nature; however, in this case, the paradox is purely nominal.

The opposition seems more essential, when the same dichotomy between the "natural" and the "artificial" serves Wilkins as the basis for a dual classification within the system of signs. In general, as far as Wilkins's assertions about meaning are concerned, we may say that whatever he calls "natural", in his catalogue of various ways of signifying, is based on resemblance, whereas signification that comes from an established custom and agreement is grounded on difference. In the former type of signification, the "natural" refers to the nature of the thing represented, while human agency consists primarily in the recognition of the resemblance or correspondence. Wilkins's distinction between the two types of signification is best exemplified by his discussion of signs and gestures that signify either ex congruo or ex placito. ${ }^{13} \mathrm{Ex}$ congruo signification takes place when "there is some natural resemblance and affinity betwixt the action done, and the thing to be express" (Mercury, 111). Among ex congruo signs Wilkins places gestures. Like Bulwer, he finds them a natural way to express passions, and observes that, in nature, gestures must come before speech and writing, because "Infants are able this way to express themselves, before they have the benefit of

13 Notably, both the nomenclature and definitions presented in Mercury closely resemble the classification proposed by Bacon in The Advancement of Learning: "These notes of cogitations are of two sorts; the one when the note has some similitude or congruity with the notion: the other ad placitum, having force only by contract or acceptation" (The Advancement of Learning, 166-167). 
Speech" (Mercury, 8). What is more, body language, being a natural means of expression, does not admit deception; on the contrary, it may even discover the duplicity of speech. To confirm this statement Wilkins invokes the authority of the Bible, which again makes the modern reader aware that, in this heterogeneous book, an empirical observation of infantile behaviour seems of equal epistemological value as a quotation from the Proverbs: "And the Wiseman notes it of the scorner, that hee winketh with his eyes, hee speaketh with his feet, hee teacheth with his fingers (Mercury, 112). ${ }^{14}$ Other signs classified as "natural" are emblems and hieroglyphs, which are characters expressing things and notions, "grounded upon some resemblance in the property and essence of the things themselves" (Mercury, 104).

In contrast to natural gestures (or natural emblems), a method of communication such as the sign language of the deaf and dumb signifies ex placito, because these signs "have their signification from use and mutual compact" (Mercury, 113). This time it is a classical literary text that provides the author with an example of ex placito signification, when he quotes the Ovidian instructions to secret lovers. ${ }^{15}$ Clearly, Wilkins felt obliged to acknowledge first those "lascivious intimations" to which invented secret gestures are so well suited, before he could move on, with easy conscience, to more socially acceptable and useful applications of those signs in commerce or in the language of the deaf and dumb.

What Wilkins particularly emphasises is the variety of those artificial means of discoursing; he derives this diversity from man's ingenuity as much as from the principle of difference:

The particular ways of discoursing by Gestures, are not to be numbered, as being almost of infinite variety, according as the several Fancies of men shall impose significations upon all such signs or actions, as are capable of sufficient difference.

(Mercury, 115)

This principle extends to all conventional signs that can be perceived by any of the senses:

For in the general we must note: That whatever is capable of a competent difference, perceptible to any sense, may be sufficient means, whereby to express Cogitations. It is more convenient indeed that these differences should be of as great a variety, as the letters of the Alphabet; but it is sufficient if they bee but twofold, because two alone, may with somewhat more labour and time, be well enough contrived to express all the rest.

(Mercury, 131-132) $)^{16}$

Wilkins's quote comes from Proverbs 6.13.

Although Wilkins gives Ovid's Ars Amatoria as his source, the passage actually comes from Amores, translated by Christopher Marlowe.

16 The concept appears also in Bacon's The Advancement of Learning: "For whatsoever is 


\section{Matter of convention and mutual consent}

To Wilkins, the potential of sufficient difference coupled with human ingenuity seems unlimited, in comparison with signification based on resemblance. Yet, unlike the latter, conventional and artificial sign systems depend on mutual agreement. This is evident in all cryptographic examples discussed by Wilkins. In case of any invented cypher or alphabet, it is necessary that at least "two Friends must before-hand, by compact, agree" upon some key "serving both to close, and to unlock the writing" (Mercury, 57). Later, in the Essay, he extends this principle to all existing human languages, pointing out the arbitrary nature of a linguistic sign: "The Names given to these [things] in several languages, are such arbitrary sounds or words, as Nations of men have agreed upon, either casually or designedly, to express their Mental notions of them" (Essay, 20). ${ }^{17}$ Thus, languages in general are based on social consensus and are part of the system of social interactions, as the opening sentence of Mercury apparently suggests:

Every rational Creature, being of an imperfect and dependent Happiness, is therefore naturally endowed with an Ability to communicate its own Thoughts and Intentions; that so by mutual Services, it might the better promote itself in the prosecution of its own Well-being.

(Mercury, 1)

What strikes us here is the circularity of Wilkins's argument: if language is based on mutual agreement and social consensus, it is, at the same time, responsible for sustaining those mutual services. This paradox, as much as other contradictions and inconsistencies spotted so far in Wilkins's early pamphlet point to the author's (as much as his contemporaries') ambivalent attitude towards language. While we could read at one point that language is an attribute of a rational soul and a gift from God, the passage quoted above presents it more as a supplement bestowed on man to compensate for the imperfection inherent in human nature. Here, communication seems no longer an essential desire of the rational soul to freely express its cogitations; it becomes rather a social imperative for the human being dependent on mutual services. Notably, Wilkins writes his pamphlet at the very moment when the proper functioning of the system of social interactions sustained by language is threatened by the imminent Civil War. In view of this fact, Mercury, being a guide on secret

capable of sufficient differences and those perceptible by the sense, is in nature competent to express cogitations (The Advancement of Learning, 166).

17 As Rhodri Lewis points out, Wilkins's artificial language "could justifiably claim to be less arbitrary than conventional languages", even though "the Essay's lexis is based on arbitrarily imposed radicals and grammatical marks", as there is "some sort of natural relations between the parts of Wilkins's projected linguistic signs" (Lewis 2007: 166). 
writing, undoubtedly, comes at just the right time; however, the art of cryptography is this type of communication, which, while based on mutual agreement and alliance, simultaneously, betokens discord and deception.

7. Volubility of speech and the invention of writing

At the end of Mercury, Wilkins shows awareness of possible "unlawful courses" that his book on secret communication may inspire, since it "may teach how to deceive" (Mercury, 171). Yet he defends his project in a way that could well serve a modern scientist as an argument in defence of a controversial invention: "it will not follow", Wilkins persuades, "that every thing must be supprest, which may be abused" (Mercury, 171). The author's defence of cryptography extends beyond secret writing to include the invention of letters and, apparently, also language in general:

\begin{abstract}
There is nothing hath more occasioned Troubles and Contention, than the Art of Writing ...; And yet it was but a barbarous act of Thamus, the Egyptian King, therefore to forbid the learning of Letters: We may as well cut out our Tongues, because that member is a world of wickedness. If all those useful Inventions that are liable to abuse, should therefore be concealed, there is not any Art or Science, which might be lawfully profest.
\end{abstract}

(Mercury, 172)

Hence while Wilkins may seem confused about the origin and nature of existing spoken languages (as some of the Mercury's internal contradictions suggest), he is fairly confident about writing and literacy being an invention of human art. Yet, he relegates this useful, albeit controversial invention, into the sphere of myth, where its ethically and epistemologically doubtful status is enacted in three different myths of origin.

The title of the book and the first chapter identify Mercury as the inventor of the alphabet, as well as the swiftest and most trusty messenger. However, in conclusion the author feels obliged to acknowledge the ambiguous status of this deity, as "the chief Patron of Thieves and Treachery" (Mercury, 171). Then, Wilkins mentions two different myths of the origin of literacy, where the art of writing is associated with some controversy. Firstly, Cadmus is identified as the father of letters, at the same time being the one "fabled to have sown Serpents Teeth" (Mercury, 172). Secondly, Wilkins turns to Plato's account of an Egyptian King Thamus' disagreement with the god Theuth over the latter's invention of writing and his claim as to its usefulness in learning. Taking the side of the god against the sceptical Thamus, Wilkins implicitly disagrees with Socrates and his derisive remarks on the written language. ${ }^{18}$ In Plato's

18 The story of Thamus appears in Plato's Phaedrus, 274d-275b. 
Phaedrus, Socrates defends "the speech of the man who knows, living and vital, of which the written version should rightly be called an image or phantom" (Phaedrus 276a); written words are like paintings, they "stand there as if they were alive, but ask them a question, and there's deathly silence" (Phaedrus 275d).

Wilkins does not seem to have been daunted by this critique of writing as void of real presence, when pursuing his cryptographic and, later, his universal language projects, even though both rely heavily on the art of letters. Moreover, it was rather speech (associated with the classical notion of eloquentia), not the invention of writing, that Wilkins and his colleagues from The Royal Society tended to be more suspicious of. Implicitly, it is the confusing "noise" of speech that Thomas Sprat denounces in his History of the Royal Society: "this vicious abundance of Phrase, this trick of Metaphors, this volubility of Tongue, which makes so great a noise in the World" (History of the Royal Society, 112). Thus the scholars seem to value a silent experiment more than the art of eloquence. ${ }^{19}$ True, Wilkins envisaged a possible phonetic system that would allow the expression in speech of the typographic system of the real characters; however, like most of the seventeenth-century language planners, he also inverted the Aristotelian order by giving primacy to the written over the spoken word (Lewis 2007: 227).

Nevertheless, the "silent" writing may be potentially as eloquent and wilful as speech, as one of the miscellaneous examples collected in Mercury very suggestively depicts. While admiring the ingenuity of writing, Wilkins tells a story of an Indian slave who was sent by his master with a basket of figs and a letter which stated how much fruit there was. ${ }^{20}$ The Indian ate some of the figs unaware that when he delivered the figs the letter would "speak" against him and discover his theft. When the slave was sent again on a similar errand he made sure this time that the letter would not "see" him when he ate the fruit and hid it under a stone; but again the letter bore witness to his guilt and eventually made him confess the theft. While the Indian might have admired "the divinity of the paper", and Wilkins the excellence of the invention, we may assume that King Charles I must have felt devastated when letters written in his own hand, "spoke" against their author instead of preserving "deathly silence", as Socrates would expect.

\footnotetext{
19 For a discussion of The Royal Society's attitude towards language and rhetoric, and towards the art of eloquence as opposed to scientific experiment see Lia Formigari (1988: 52-55); John Wallis's letter to Robert Boyle that Formigari refers to seems to be of particular interest here.

20 As has been mentioned above, the story was employed by Umberto Eco for the purpose of his argument on the limits of interpretation. See Eco (1992: 40-41).
} 


\section{Conclusion}

All in all, Wilkins's Mercury is as much a practical guidebook on means of secret communication, as it is a survey of the contemporary theories of language. Some propositions, such as the arbitrariness and conventionality of language or the concept of meaning as produced by a system of differences, may seem familiar to the modern reader. However, the curious miscellany of examples - empirical, philosophical, mythological, literary, and biblical - calls into question Wilkins's method, as some of his statements would not be accepted as scientifically true in modern scientific discourse. However, the ambiguities and inconsistencies permeating Wilkins's theories of language that he put forward in Mercury may not only have resulted from the discrepancy between the author's and the readers' epistemological frameworks. They seem to stem as much from the seventeenth-century ambivalent attitudes towards language. They are shaped by the nature of language itself, "with its mixture of consistency and inconsistency"; that fickleness of the object of study which, as Hüllen observes, "finally gained the upper hand over the plan of an artificially perfect language" (Hüllen 1999: 276). Had Wilkins fully recognized this willfulness and unruly energy of language, no matter whether spoken or written, he might have abandoned his heroic, yet utopian, scheme of taming it within a systematic frame - a scheme which he never perceived as being completed, and which, like all the contemporary philosophical language projects, was never really put into practice.

\section{REFERENCES}

\section{PRIMARY SOURCES}

Bacon, Francis. 1900. The advancement of learning. Edited by William Aldis Wright. Oxford: Clarendon Press.

Bulwer, John. 1644. Chirologia: or the naturall language of the hand. London. Internet Archive. http://archive.org/details/gu_chirologianat00gent (30 November 2012).

Locke, John. 1996. An essay concerning human understanding. (Great Books of the Western World. 33.) Chicago: Encyclopaedia Britannica, Inc.

Plato. 2000. Symposium and Phaedrus. Trans. Tom Griffith. (Everyman's Library 194.) London: Everyman Publishers.

Sprat, Thomas. [1667] 1958. History of the Royal Society of London, for the improving of natural knowledge. London. Edited with critical apparatus by Jackson I. Cope and Harold Whitmore Jones. St. Louis \& London: Washington University Press/Routledge and Kegan Paul.

Wilkins, John. 1668. An essay towards a real character, and a philosophical language. London: Printed for Sa. Gellibrand and for John Martyn. 
Wilkins, John. 1694. Mercury, or, The secret and swift messenger. Shewing, how a man may with privacy and speed communicate his thoughts to a friend at any distance. 2nd edn. London: Printed for Richard Baldwin.

\section{SECONDARY SOURCES}

Borges, Jorge Luis. 2001. The total library: Non-fiction 1922-1986. Edited by Eliot Weinberger. Trans. Esther Allen, Suzanne Jill Levine \& Eliot Weinberger. London: Penguin Modern Classics.

Cohen, Murray. 1977. Sensible words: Linguistic practice in England, 1640-1785. Baltimore: Johns Hopkins University Press.

De Grazia, Margreta. 1980. The secularization of language in the seventeenth century. Journal of the History of Ideas 41.2. 319-329.

Eco, Umberto, Richard Rorty, Jonathan Culler \& Christine Brooke-Rose. 1992. Interpretation and overinterpretation. Edited by Stefan Collini. Cambridge: Cambridge University Press.

Eco, Umberto. 1995. The search for the perfect language: Making of Europe. Trans. James Fentress. Malden: Blackwell Publishing.

Formigari, Lia. 1988. Language and experience in $17^{\text {th }}$-century British philosophy. Amsterdam \& Philadelphia: John Benjamin Publishing Company.

Foucault, Michel. 1980. Power/knowledge: Selected interviews and other writings 1972-1977. Edited by Colin Gordon. New York: Pantheon Books.

Foucault, Michel. 1994. The order of things: An archaeology of human sciences. New York: Vintage Books.

Hüllen, Werner. 1999. English dictionaries, 800-1700: The topical tradition. New York: Oxford University Press.

Knowlson, James. 1975. Universal language schemes in England and France, 1600-1800. Toronto and Buffalo: University of Toronto Press.

Lewis, Rhodri. 2007. Language, mind and nature: Artificial languages in England from Bacon to Locke. Cambridge: Cambridge University Press.

Shuger, Debora K. 1997. Habits of thought in the English Renaissance: Religion, politics and the dominant culture. Toronto: University of Toronto Press.

Slaughter, Mary M. 1982. Universal languages and scientific taxonomy in the seventeenth century. Cambridge: Cambridge University Press.

Stillman, Robert E. 1995. The new philosophy and universal languages in seventeenth-century England: Bacon, Hobbes, and Wilkins. London: Associated University Press.

Subbiondo, Joseph L. 1990. John Wilkins's theory of the origin and development of language: Historical linguistics in 17th-century Britain. In Hans-Joseph Niederehe \& Konrad Koerner (eds.), History and historiography of linguistics, 357-365. Amsterdam \& Philadelphia: John Benjamins Publishing Company.

Varela, Francisco J., Evan T. Thompson \& Eleanor Rosch. 1991. The embodied mind: Cognitive science and human experience. Cambridge, Massachusetts: Massachusetts Institute of Technology Press.

Waswo, Richard. 1987. Language and meaning in the Renaissance. Princeton: Princeton University Press. 